Encounters in Theory and History of Education

Rencontres en Théorie et Histoire de l'Éducation

Encuentros en Teoría e Historia de la Educación

\title{
Artwork and Contributing Artists
}

Volume 21, 2020

URI : https://id.erudit.org/iderudit/1077866ar

DOI : https://doi.org/10.24908/encounters.v21i0.14455

Aller au sommaire du numéro

Éditeur(s)

Faculty of Education, Queen's University

ISSN

2560-8371 (numérique)

Découvrir la revue

Citer ce document

(2020). Artwork and Contributing Artists. Encounters in Theory and History of Education / Rencontres en Théorie et Histoire de l'Éducation / Encuentros en

Teoría e Historia de la Educación, 21, 288-291.

https://doi.org/10.24908/encounters.v21i0.14455 


\section{Artwork and Contributing Artists}

\section{TINA BETZ}

Title: "Nurture" (2001)

Medium: enameled, flameworked and cast glass, brass

Size: $11.5 " \mathrm{~h}$ x 13" I x 6" w

Flameworked glass watering can made up of the word "nurture" written repeatedly with the glass strands. These elaborate sculptures are created by cutting sheet glass into strips, then pulling them into strands in a flame. For the natural, organic objects the glass sheet is hand-painted with glass enamels which are fired on, allowing for a painterly and varied custom color palette. The strands are then fused together with a hand torch and built free form without molds or structures as if they were threedimensional drawings.

Tina Betz has a Masters in Fine Arts in glass and sculpture. She has been creating narrative sculptures in glass for over 30 years using this intricate glass lace-work flameworking technique she developed. She creates metaphorical associations using imagery that is, by appearance fragile and precious, yet in actuality very strong. Therefore the seemingly fragile way a sculpture is built is appropriate to the ideas behind the work. Tina Betz's sculptures are represented in many prestigious museums and private collections, most notably the Seagram's Ltd collection in NYC, and the Daiichi Museum in Japan.

From Glass Art magazine:

“...Tina Betz's flameworked pieces are characterized by their lace-like delicacy. Her work is about celebrating the feminine, family and nature and acknowledging their importance in our lives. She achieves this through an elaborate use of the seductiveness of glass..." 


\section{KRISTINA A. BOYLAN}

Title: "History Warp and Weft" (1992), digital reproduction of original work (2020) Medium: hand-painted woven fabric (cotton thread, textile dye), textured paper, pen and ink, ribbon

Transcript of calligraphed text: "During the whole of my sickness, I was nursed in a most devoted and affectionate manner by my maid Fanny. At times she actually wept over me...And yet-when I was scarce able to walk without assistance--she left me without provocation or reason-left me in the night, and that too without the slightest notice."

-Catherine Devereux Edmonston, Diarist, Civil War*

She could not read between her own lines to find out why. To comprehend Fanny's history, one must read between the lines--indeed, between the pages. No one likes to be owned--that is why Fanny had to tear herself away. Everyone who is able to walk alone should do so.

Artist's Statement: ‘The quote comes from Eugene D. Genovese's Roll, Jordan Roll: The World the Slaves Made (Vintage Books, 1976, p. 99). Genovese contrasts quotes of formerly enslaved persons discussing their deep desires for freedom amidst the denials of their humanity under the constraints of slaveholders, with quotes that demonstrate the concerted non-comprehension of the humanity of the persons forced to work in their households exhibited by slaveholders. Though Genovese cites reflections from other formerly enslaved persons, there is no quote available from Fanny to directly counter Catherine's version of events. Primary sources need to be read carefully for what they contain and what they lack, as they give us incomplete pictures of the past. When I produced this work, my goal was for the painted warp to replicate a painting I had made envisioning the scene. However, my amateur skills at loom-threading resulted in an incomplete image, one less photorealistically but more historiographically accurate.

Kristina A. Boylan received the D.Phil. in Modern Latin American History from the University of Oxford in 2001. She is an Associate Professor of History and a faculty member in the Communications and Humanities Department and the Interdisciplinary Studies Program in the College of Arts and Sciences at the State University of New York Polytechnic Institute. Her current projects include: history of Catholic women's activism in revolutionary Mexico; research and curricular teams on humanitarian engineering/studies, creative and ethical venturing, and developing multisensory learning environments; and food, gardening, and other creative learning projects with colleagues, students, and the local community. 


\section{PAUL SCHULMAN}

Moonflower unfurling (2020)

Photo was taken in the early evening in the summer of 2020 with an iPhone.

Paul Schulman is a (retired) cognitive psychologist interested in visual perception, and, like every other person interested in vision, also interested in art - photography in his case. He is also interested in the effect of learning on homeostasis.

\section{ILIAS TOLIADIS}

Title: "the lack of the vernacular" (2018)

Medium: color pencils and pencils on paper with paper collage

Size: $20 \times 30 \mathrm{~cm}$

Ilias Toliadis grew up in a border village in northwest Greece. He studied in the Fine Arts School of Aristotle University in Thessaloniki, Greece, completed his MA in Visual Arts with distinction at the University of East London, UK. and his MFA of IAMD program in OCAD University. Painting, with various techniques, from murals to canvases, is his job for more than twenty years now. Travelling, migrating, living as nomad artist has been my life for couple decades. The narratives I evoke in my studio practice, which has internalized the "magical properties" of talismanic objects, are efforts to employ cultural and experiential fragments, make them intelligible to myself and relevant for my current reality. This methodology has become a ritualized interdisciplinary process of healing itself and a rich area of symbolism and meaningmaking crucial for nomadic artistic practice. Unlike objects, practice does not need to be transported. This quality, in tandem with an inherited sense of mobility and potential for new discoveries in art, creates a momentum of practising freedom that helps towards integration. Ilias has shown his work in various galleries, art spaces and community centers in Greece, England, Scotland as well as in the U.S., Canada, Egypt, Italy, Spain.

\section{JIA ZHOU}

Title: "Guria" (2020)

Medium: mineral color and Ink on rice paper

Jia Zhou was born in Nanchang, China in 1990. Jia Zhou graduated from Jingdezhen Ceramic Institute in 2011 with a degree in Ceramic Design; she then obtained her Master of Art degree at Jiangxi Science and Technology Normal College in 2014, where she continued her studies in Chinese painting. She currently works as a full time artist and resides in the United States. Jia continues her explorations of the many branches of the art world, and continues to create with native Chinese traditional techniques whilst also reaching out to classical western influences to produce work 
that pays homage to her homeland. Jia works privately yet uses modern technology to link with accomplished artists around the globe and liaises openly with them using their input to develop her rapidly advancing intrinsic yet expressive style. Her compositions are drawn from her drive to study flora, fauna and wildlife both around her and from the world at large and incorporate them into a style using ink and mineral colors on her beloved rice paper and silk. Since 2014 her work has appeared in exhibitions in the Netherlands, Austria, Italy, Germany, Hong Kong, and now the United States of America. 